UDC 378.14:004

DOI: $10.52534 / \mathrm{msu}-$ pp.7(2).2021.101-108

Viktoria V. Kondratenko, Ihor A. Zaitsev ${ }^{\star}$, Alexander M. Nesterenko
Liudmyla V. Homon, Gennady N. Chykolba

University of Customs and Finance

49000, 2/4 Volodymyr Vernadskyi Str., Dnipro, Ukraine

\title{
Modern Information Technologies in the Process of Physical Education in Universities of Ukraine
}

\section{Article's History: \\ Received: 01.03.2021 \\ Revised: 25.05.2021 \\ Accepted: 16.06 .2021}

\section{Suggested Citation:}

Kondratenko, V.V., Zaitsev, I.A., Nesterenko, A.M., Homon, L.V., \& Chykolba, G.N. (2021). Modern information technologies in the process of physical education in universities of Ukraine. Scientific Bulletin of Mukachevo State University. Series "Pedagogy and Psychology", 7(2), 101-108.

\begin{abstract}
The relevance of the study is determined by the need to update the methods of teaching physical culture in universities based on information technologies in accordance with the socio-cultural conditions of the present time. The purpose of the study is to substantiate the need to use information technologies in physical education in Ukrainian universities, followed by the development of a conceptual model based on the experience of foreign higher education institutions. The research of the selected problem was conducted in two stages based on systematic and innovative approaches using the method of analysis, synthesis, generalisation, systematisation, and comparison. The paper identified the need to introduce information technologies in the educational process of physical culture in universities based on the research of Ukrainian and foreign authors. The article analysed and compared the practices of using information technologies in physical education classes in universities of European countries, such as Spain, Ireland, Portugal, the Russian Federation, as well as Asian countries, among which are Japan and China. It was found out that the introduction of informatisation tools in the educational process of physical education in Ukrainian universities is accompanied by certain difficulties, and at the same time, the actualisation of the search for solutions to these problems was identified. The main ways of introducing information technologies in physical education classes in leading Ukrainian universities were considered. Based on the experience of Ukrainian and foreign universities, a conceptual model of information technologies usage in the educational process of physical education was developed, which is based on improving individual and collective skills using a universal mobile application and fitness games. The value and prospects of further research lie in creating a universal mobile application and implementing the author's methodology in practice
\end{abstract}

Keywords: physical development, conceptual model, physical competence, informatisation, digital technologies, university

\section{INTRODUCTION}

The modern educational and professional paradigm provides for comprehensive and competency-based growth of each individual in accordance with specific conditions. Thus, the Law of Ukraine "On Physical Culture and Sport" recognises physical culture as "one of the most important factors of comprehensive personal development" [1]. However, today there is a problem related to the involvement of higher education students in physical education. First of all, this is due to the lack of motivation among students and the negative experience gained during physical education lessons at school. As a result, the teacher of a university faces the task of not only analysing the students' motives to engage in physical culture, but also forming appropriate learning conditions that will contribute to the growth of interest and involvement of higher education students in the educational process itself. In accordance with this, there is an increase in the relevance of the use of information technologies in pedagogical practices, which are becoming almost a key means of encouraging students to physical education.

Taking into account a number of studies by Ukrainian and foreign scientists, the problem of using modern information technologies in the process of physical education in universities has remained relevant for a long time. For example, N. Chekmarova and I. Cherkasov stated that "one of the main forms of education in modern pedagogy is the search for effective approaches and the introduction of new 
innovative technologies in physical education classes" [2]. For his part, Yu. Zabiyako in his research considered innovative methods of teaching physical culture, including the use of multimedia, integrated, game, collective technologies, as well as technologies for individualising the learning process [3]. At the same time, it is advisable to refer to the best practices of N. Hladun [4]. According to the author, "the use of information and communication technologies in physical education classes is an unconventional approach to teaching, which allows increasing the amount of material learned since it affects the consciousness, feelings, and actions of the student" [4]. A. Sushchenko notes that "the use of information technologies increases labour productivity, helps to focus on the main points of educational material, and also reduces unproductive costs for information search and processing time" in physical education classes [5]. At the same time, the results of the scientific research of N. Chukhlantseva [6] are interesting for the author's study. The researcher believes that "the most popular computer technologies in the field of physical culture are teaching tools that improve the quality of teaching and control, testing programmes, and control of the training process, as well as applied software products that are aimed at processing information, for example, during competitions" [6].

At the same time, it is worth paying attention to the results of research by foreign scientists on the chosen issue. Thus, the Chinese scientist S. Wang, using the methods of scientific analysis, questionnaires, and mathematical statistics, proved the need to create a local network called Campus Network within a university in order to improve the process of teaching physical culture [7]. Thus, the specified network provides open access to any necessary information, which further contributes to improving the competence of both teachers and students [7]. For his part, the scientist $\mathrm{X}$. Zhao substantiated the advantages of using multimedia technologies in physical education classes, among which are: optimisation of the physical education environment, improvement of aesthetics and development of students' feelings, as well as enrichment of educational material and stimulation of interest in learning [8].

As is evident, the problem of technologisation in the process of physical education in universities requires clear methods of solution, which determines the need for scientific research. Therefore, the purpose of the work is a substantiation for the need to introduce modern information technologies in the process of physical education in Ukrainian universities with the subsequent development of a conceptual model based on the experience of foreign universities. To achieve this purpose, the following tasks were defined:

1. To analyse the experience of introducing information technologies in the process of physical education in foreign universities based on scientific research by foreign authors.

2. To describe the state of introduction of information technologies in physical education classes in Ukrainian universities.

3. To form author's conceptual model of using information technologies in physical education of students.

\section{MATERIALS AND METHODS}

The study of the problem of using modern information technologies in the process of physical culture in Ukrainian universities was conducted in two stages. The first stage analysed the experience of foreign universities in order to further implement it in Ukrainian universities, as well as the experience of Ukrainian universities in order to identify key motives and problems of using information technologies during physical education classes. The second stage provided for the creation of author's conceptual model of using information technologies in the educational process of students' physical culture based on the data obtained at the first stage of the study.

In general, in the process of studying the chosen issue, the author used such general scientific theoretical methods as analysis, synthesis, comparison, generalisation, and systematisation. The methods of analysis and synthesis were used to study scientific papers over the past 3-5 years of Ukrainian and foreign researchers who studied the problem of using information technologies in the process of physical education of higher education students in Ireland, Portugal, Spain, the Russian Federation, Japan, China, and Ukraine, in particular. The comparison method helped to correlate the experience of European and Asian countries, as a result of which the difference in methods of teaching physical culture, as well as the use of information technologies in the educational process, was clarified. In order to summarise the obtained data after the analysis and synthesis of the processed literature, the method of generalisation was used, based on which a conceptual model for the use of information technologies in physical education classes in universities was formulated. The method of systematisation was used to reproduce the ways of using information technologies in the process of physical education of Ukrainian universities such as Kharkiv State University of Food Technology and Trade, National Technical University "Igor Sikorsky Kyiv Polytechnic Institute" and Prydniprovsky State Academy of Physical Culture and Sports.

Based on a systematic approach in the combination of two components, the author's methodology for applying information technologies in the process of physical education of students was formed, which provides for the improvement of individual and collective physical competence skills through information tools, including a universal mobile application with an individual physical development programme and fitness games. The innovative approach in the research process is focused on the idea of creating a universal mobile application for the purpose of using it during physical education classes in a university, which will allow students to physically improve themselves both during university classes and after completing physical education training course.

As a theoretical basis for the study of the chosen problem, a legislative and regulatory document was used, such as the Law of Ukraine "On Physical Culture and Sport" [1], which made it possible to define physical culture as one of the key aspects of versatile personal development. 
RESULTS AND DISCUSSION Information technologies in the process of physical education in universities: World experience

It is worth starting with the fact that the experience of introducing information technologies in the process of physical education in universities abroad is much more powerful than within the Ukrainian space. This is due to a number of reasons, yet, first of all, it concerns the economic and financial prerequisites that make it possible to provide certain education institutions with proper equipment and qualified specialists. At the same time, even taking this aspect into account, there is a need to analyse the practices, which will form a proper idea of the general state of informatisation of the educational process in foreign countries and help identify key methods of teaching physical education in order to apply them in Ukrainian education. In this context, it is advisable to refer to the positive experience of using information technologies in physical education classes in such countries as Ireland, Portugal, Japan, China, the Russian Federation, and Spain.

First of all, it is advisable to consider the educational practices of Ireland. In recent years, in Ireland, the use of digital and information technologies as a means of teaching and learning within physical education has increased significantly, as S. Crawford and P. Fitzpatrick draw attention to in their research. [9]. At the same time, the authors describe an interesting experience of informatisation of students' physical education, which involves the use of portable iPod media players. Owing to electronic media, students not only form their digital competence, but also learn the necessary material much faster and enjoy physical activity. In addition, portable media players help to adapt physical activities to certain age and physical characteristics of each individual student [9]. In this context, it is worth mentioning the experience of implementing information technologies in physical education classes in Portugal. According to J. Escola, modern methods of teaching physical culture do not meet the requirements of society, as a result of which there is a need for radical renewal [10]. That is why in Portugal, physical education teachers are encouraged to use video equipment, interactive whiteboards, and Web 2.0. projects, which significantly expand the possibilities of receiving, processing, and transmitting information [10].

At the same time, an extremely powerful base of empirical research on the introduction of information technologies in physical education classes is concentrated in Spain, based on which it is possible to trace the positive and negative trends of the country's experience. It is worth starting with the fact that the process of introducing information technologies involves overcoming certain problematic aspects. Thus, according to the results of a questionnaire of teachers conducted by A. Villalba and M. Gonzalez-Rivera, the majority of higher education workers recognise the necessity and expediency of using information technologies in physical education classes, however, in the process of mastering informative competence, teachers face a number of problems [11]. First of all, this refers to spending time on physical activity, lack of resources, lack of time, improper use of knowledge or insufficient level of information awarness, and also technical problems [11]. For their part, E. Crisol Moya and M. Caurcel Cara conducted an empirical study at the University of Granada to find an appropriate solution to the problem of teaching physical culture in higher education institutions [12]. Thus, the researchers, following on from the results of a students' questionnaire, substantiated the expediency of using active methodologies during physical education classes, and also proposed a model of structural balance that establishes the relationship between three components: organisational modalities, methodological features, and an assessment system, which allows both properly organising the process of physical education, and maximising students' interest in physical culture [12]. At the same time, one of the methods for solving the problem of using information technologies in physical education classes was proposed by Spanish researchers R. Cuberos, M. Sanchez, and F. Ortega [13]. Information and communication technologies form the learning process, so it is extremely relevant to use fitness games in physical education classes [13]. This type of activity allows mastering basic physical skills, form students' general ideas about individual sports, and motivate higher education students to be physically active. It is also worth noting that in Spanish universities, special attention is focused on the use of modern information technologies during physical education classes for students with disabilities [14]. In this case, according to J. FernandezBatanero and B. Sanudo, the role of information technologies is particularly important, since they make physical education classes accessible for students with disabilities in accordance with the physical characteristics of each student [14]. As is evident, the experience of introducing the latest technologies in the educational process of physical culture in universities in Spain has its own problematic aspects, however, in this context, it is necessary to take into account empirical research that encourages changes.

In addition, in the process of studying the practices of using modern information technologies in the process of physical education in universities, it is advisable to refer to the experience of the Russian Federation. Thus, the St. Petersburg State University of Film and Television developed a distance learning technology based on the Moodle system with a course of lectures and assessment of students' academic performance, as well as provided digital practical recommendations on physical self-education based on digital textbooks and video material [15]. At the same time, in Udmurt State University, information technologies in the field of students' physical education are used to form a system of sports training, to organise and manage sports events, as mechanisms for organising theoretical and practical work, as functional and psychological tests, and as methods for monitoring the physical condition of students [16].

Taking into account the socio-cultural differences between East and West, it is worth considering separately the Asian experience of introducing information technologies in physical education classes in universities on the example of Japan and China. Thus, the scientists from the Tokyo 
University of Liberal Arts described the peculiarities of using information and communication technologies, the essence of which is to move away from behavioural physical education training to constructivist [17]. This approach focuses on the use of information technologies not to improve the performance of movements during physical education, but to increase awareness of the importance of physical education classes and encourage the creation of new ideas through exercises [17]. In general, information technology was classified according to three parameters: activity visualisation settings, problem solving settings, and evaluation settings. At the same time, N. Suzuki and S. Okuma emphasise the use of information technologies in combination with others, which will allow establishing a direct link between needs and awareness [17]. Turning to the experience of Chinese universities, it should be noted that the level of information technologies usage in physical education classes was quite low [18]. The Scientist Q. Chen conducted an empirical study, based on which it was found that, for the most part, physical education teachers use information technologies only during "open" lessons, that is, in fact, information technologies appear as a means of meeting teachers' own needs, and not one of the key methods of teaching students [18]. Thus, the approach to the use of information technologies in the educational process was changed, focused on interaction between the teacher and the student, as well as increasing the volume and level of availability of information [18].

Thus, as is evident, the positive trends in the world experience of using information technologies in physical education classes in universities indicate a successful solution of all problematic aspects in the very process of their implementation. At the same time, it is advisable to note the characteristic differences between the implementation methods of the countries of the European and Asian regions.
Based on cultural and ideological features, it is advisable to point out that the methods of introducing information technologies in Western universities are focused on the very fact of attracting students to physical culture, while in universities of Eastern countries, attention is aimed at increasing the level of students' awareness. Such an analysis of world practices allows forming author's conceptual model of the use of information technologies in the process of physical education in Ukrainian universities.

\section{Ukrainian methods of applying information technologies during physical education classes in universities}

Modern cultural, social, and economic conditions of the Ukrainian space have led to the actualisation of the problem of using information technologies in the educational process, in particular during physical education classes in universities. At the same time, the actualisation of this problem is accompanied by a number of dilemmas, the lack of solutions to which suspends the introduction of information technologies. In this context, it is advisable to turn to the practices of using information technologies in physical education classes in specific universities, including Kharkiv State University of Food Technology and Trade, National University of Physical Education and Sport of Ukraine, National Technical University of Ukraine "Igor Sikorsky Kyiv Polytechnic Institute" and Pridneprovsky State Academy of Physical Culture and Sports.

Thus, turning to the methods of teaching physical culture at the Kharkiv State University of Food Technology and Trade, it is advisable to point out that the use of information technologies during physical education classes in a university is solely an auxiliary tool [19]. At the same time, there are three areas of use of information and communication technologies in the educational process of Kharkiv State University of Food Technology and Trade (Fig. 1):

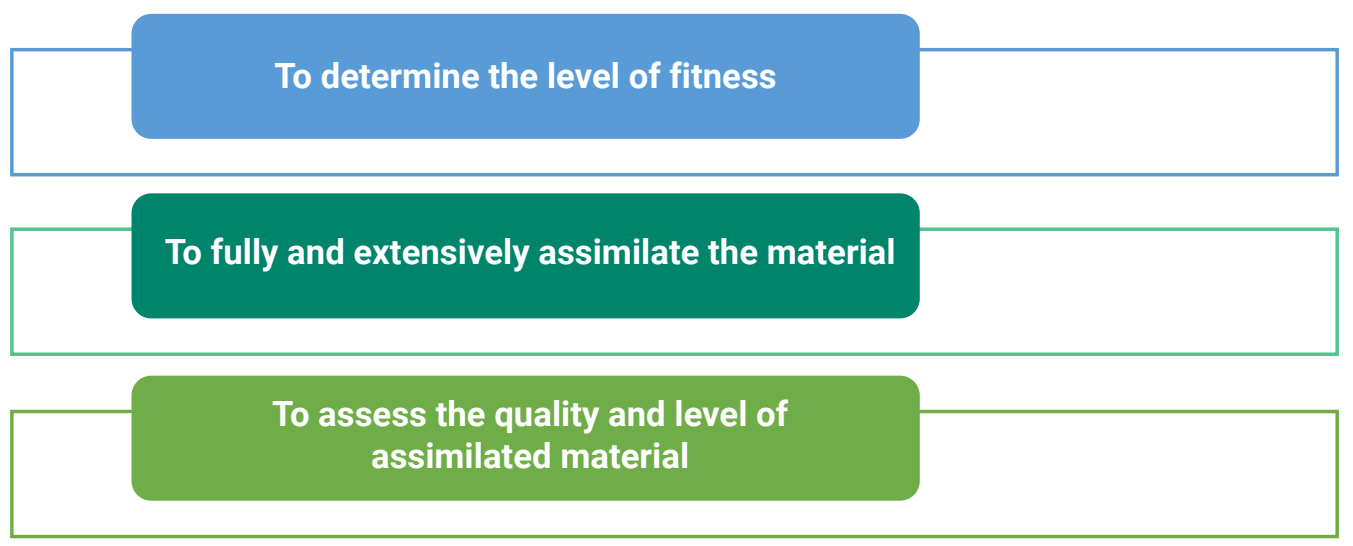

Figure 1. The areas of using information technologies during physical education classes at Kharkiv State University of Food Technology and Trade

Source: compiled by the author based on data [19]

At the same time, among information and communication technologies, the most used in physical education classes are Internet resources, presentations, and videos to provide visibility, as well as the use of interactive whiteboards and software [19]. In addition, it is worth paying attention to the use of information technologies at the National University of Physical Education and Sport of Ukraine. According to the specialised field of the university, its experience in implementing information technologies in the process of physical education differs significantly from the practices of other Ukrainian education institutions. First of all, this is due to the use of hypermedia information environments, computer programmes, including "Psychophysiological diagnostic system" and "Fitball training", as well as automatic 
surveillance systems, which should include Expert Vision Analysis, Motion Analysis Corp., Vicon, CODA, etc. [20]. One way or another, automatic surveillance systems make it possible to properly track and record movements in real time, and computer programmes significantly improve the process of practicing certain sports [20]. In this context, it is interesting to consider the experience of the National Technical University of Ukraine "Igor Sikorsky Kyiv Polytechnic
Institute". The characteristic feature of using information technologies during physical education classes in a university is to create an educational and control programme that is aimed at using both full-time and distance learning. At the same time, the training envisages the use of the computer programme "Psychophysiological diagnostic system" [20]. In general, the training and control programme consists of two blocks: training and controlling (Fig. 2).
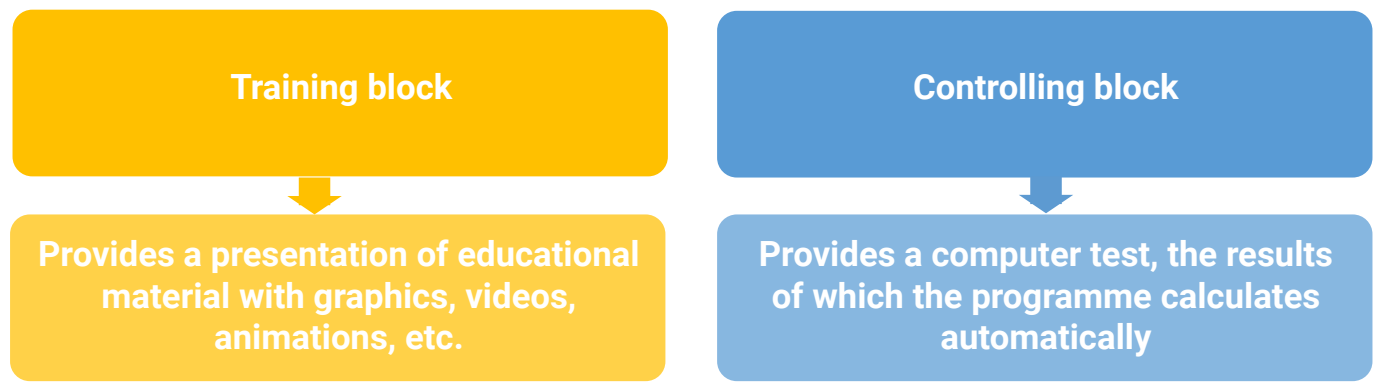

Figure 2. The scheme of the training and control programme for physical education Source: developed by the author based on source [20]

As is evident, the educational and control programme is aimed at mastering theoretical material, and at the same time, the programme presents independent work that allows choosing the desired topic and implement the knowledge gained in practice [20]. The emphasis on the use of computer programmes in the educational process of physical education is also made in the Pridneprovsky State Academy of Physical Culture and Sports [21]. Thus, among the main computer software, the following programmes were found (Fig. 3):
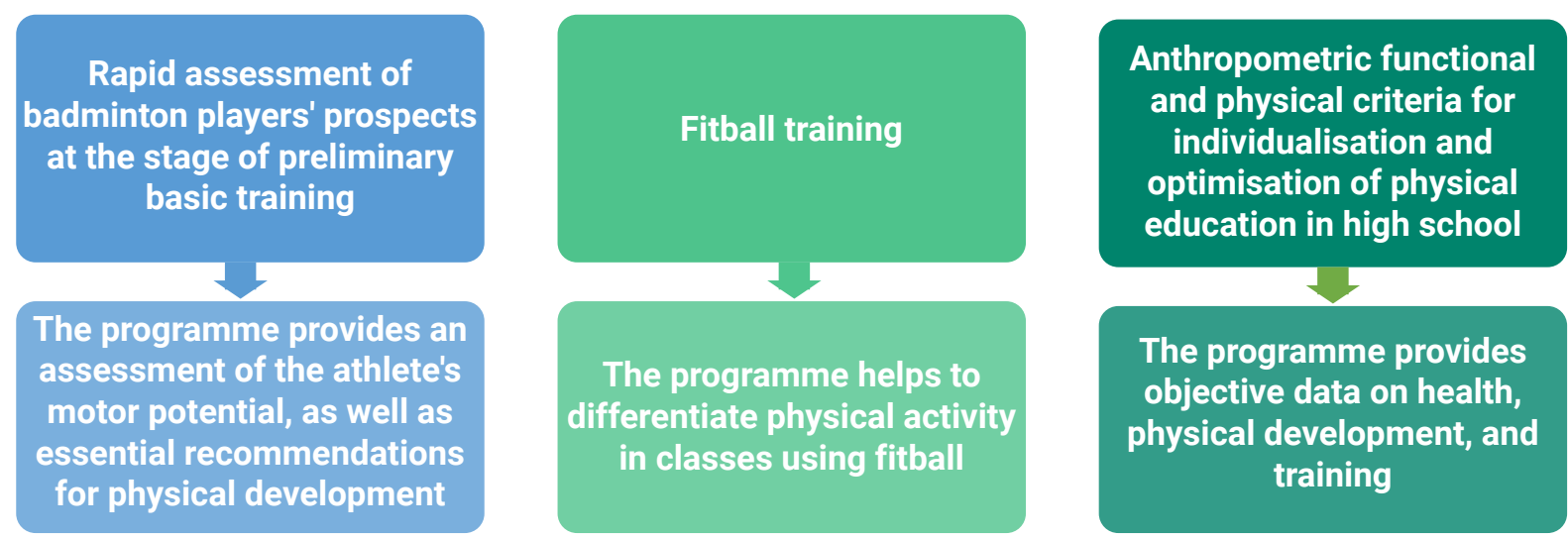

Figure 3. Examples of computer programmes for using in physical education classes in Pridneprovsky State Academy of Physical Culture and Sports

Source: developed by the author based on source [21]

Finally, the level of information technologies usage during physical education classes in Ukrainian universities differs significantly, however, the general characteristic is still the focus on updating the educational process of physical culture by means of information technologies. Thus,

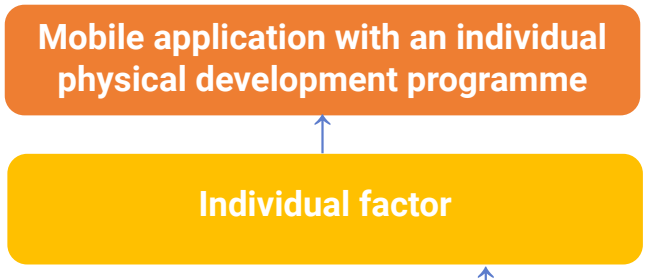

based on the analysed world and Ukrainian experience in implementing information technologies, the authors offer the conceptual model, which provides for the use of information technologies both for the development of individual and collective components of physical competence (Fig. 4).

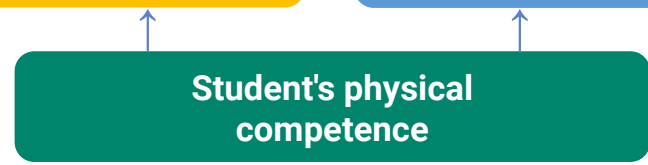

Figure 4. The conceptual model of using information technologies in physical education of university students Source: compiled by the author 
As is evident, the conceptual model of using information technologies in physical education of university students is aimed at forming students' physical competence based on the development of individual and collective factors. At the same time, each of these factors involves the use of specific information technologies, which, in general, will ensure the equal development of all skills.

First of all, the individual factor should be mentioned. Ensuring the proper development of individual skills requires a special approach that focuses on using the mobile app. It should be noted that the modern information space contains many mobile applications that, in one way or another, provide assistance in the process of physical self-education. However, each of these applications is characterised by a separate specialisation, which leads to difficulties in the process of physical training. For example, a mobile app Nike Training Club is used for training with different physical levels, at the same time, a mobile application Fitness centre is used for determining the level of physical fitness, as well as setting individual goals with a focus on personal characteristics. On the other hand, a mobile app Calorie counter, the purpose of which is to control the calories consumed, track the nutrition system, and so on. As a result, it is evident that there is a need to create a universal mobile app which will perform the functions of both a "fitness trainer" and a nutritionist. Thus, it is advisable to use the universal mobile application in physical education classes in universities, which will allow choosing individual training programmes for each student in accordance with their wishes and needs. At the same time, it is worth adding that the course of physical education in a university should begin with a medical examination of students, according to the results of which the physical education teacher will set up individual programmes for physical development and nutrition systems in the universal mobile application of each student.

For its part, the collective factor involves the development of general ideas about certain sports, as well as communication and teamwork skills. The development of the communication factor is possible using modern information and digital technologies, such as fitness games. First of all, it is worth noting that the use of fitness games allows engaging in any sport, regardless of the place, weather conditions, physical characteristics, etc. In addition, fitness games provide the possibility of team game based on an interactive training method. Either way, the physical activity during fitness games is much less than during conventional classes in certain sports, according to which the teacher will have the opportunity to ensure the proper level of physical activity of those students whose health condition requires a light level of physical activity. At the same time, it is advisable to use fitness games as auxiliary means of physical education classes and, if possible, combine them with conventional sports. Thus, the conceptual model of using information technologies in the process of physical education in universities will allow students to consciously approach physical education classes, choose individual programmes of physical and nutritional development, which will significantly motivate them to physical self-improvement. At the same time, the use of a universal mobile application will provide students with the opportunity to continue physical selfeducation even after completing an academic discipline at a university.

\section{CONCLUSIONS}

The research considered the problem of introducing modern information technologies in the process of physical education in Ukrainian and foreign universities. First of all, the paper based on scientific research substantiated the need to use information technologies during physical education classes for university students. At the same time, special attention was paid to the experience of using information technologies in foreign universities in countries such as Ireland, Portugal, and the Russian Federation. The experience of Spanish universities was interesting for the author's research, the essence of which was to create a model of structural balancing, as well as the use of fitness games during physical education classes. At the same time, for comparison, the experience of Asian countries, such as China and Japan, was considered, which allowed stating significant differences in the approaches of teaching and implementing physical education information technologies in Eastern and Western universities.

In addition, the study of the chosen problem required a separate analysis of methods of introducing and using information technologies in the process of physical education in Ukrainian universities. Thus, the described the experience of Kharkiv State University of Food Technology and Trade, National University of Physical Education and Sport of Ukraine, National Technical University of Ukraine "Igor Sikorsky Kyiv Polytechnic Institute" and Pridneprovsky State Academy of Physical Culture and Sports. Finally, based on the analysed practices of Ukrainian and foreign universities, a conceptual model of the use of information technologies during physical education classes for university students was proposed, the essence of which is to form physical competence based on individual factors (mobile application with an individual physical development programme) and collective factors (fitness games) by means of information technologies.

The author sees the prospects for further research in the development of a universal mobile application and the implementation of the conceptual model in practice.

\section{REFERENCES}

[1] Law of Ukraine No. 3808-XII “On Physical Culture and Sports”. (1993, December). Retrieved from https://zakon.rada. gov.ua/laws/show/3808-12/ed19931224\#Text.

[2] Chekmarova, N.H., \& Cherkasov, I.S. (2017). The use of innovative technologies of physical education in universities. Naukovo-Metodychni Osnovy Vykorystannia Informatsiinykh Tekhnolohii v Haluzi Fizychnoi Kultury ta Sportu, 1, 121-124.

[3] Zabiyako, Yu. (2013). Pedagogical technologies of physical culture teaching. Fizychne Vykhovannia, Sport i Kultura Zdorovia u Suchasnomu Suspilstvi, 1(21), 103-106. 
[4] Hladun, N.V. (2018). Information-communication technologies to provide physical education and sport. Retrieved from https://naurok.com.ua/vprovadzhennya-ikt-na-suchasnomu-uroci-fizichno-kulturi-17958.html.

[5] Suschenko, A.V. (2012). Information-communication technologies and mean of teaching in professional preparation of future specialists on a physical culture and sport. Bulletin of Zaporizhzhia National University, 1(7), 104-111.

[6] Chuhlantseva, N. (2016). Application of information technologies in the field of physical education and sport. Sportyvna Nauka Ukrainy, 3(73), 21-25.

[7] Wang, S. (2015). The study of the construction and the practice of digital campus in sports university. MATEC Web of Conferences, 31, article number 17005.

[8] Zhao, X. (2020). Research on multimedia technology of physical education classroom combined with computer platform. Journal of Physics: Conference Series, 1486(2), article number 022008.

[9] Crawford, S., \& Fitzpatrick, P. (2015). Use of mobile digital technology and iPod touches in physical education. In Y. Zhang (Ed.), Handbook of Mobile Teaching and Learning (pp. 499-508). Berlin: Springer.

[10] Escola, J.J.J. (2018). Applications ICT in teaching physical education. Retos, 34, 371-376.

[11] Villalba, A., Gonzalez-Rivera, M.D., \& Diaz-Pulido, B. (2017). Obstacles perceived by physical education teachers to integrating ICT. Turkish Online Journal of Educational Technology, 16(1), 83-92.

[12] Crisol Moya, E., \& Caurcel Cara, M.J. (2021). Active methodologies in physical education: Perception and opinion of students on the pedagogical model used by their teachers. International Journal of Environmental Research and Public Health, 18(4), 1-18.

[13] Cuberos, R.C., Sanchez, M.C., Ortega, F.Z., Garces, T.E., \& Garces, T.E. (2016). Active videogames as ICT tool in physical education classroom: Research from digital leisure parameters. Digital Education Review, 29, 112-123.

[14] Fernandez-Batanero, J.M., Sanudo, B., Montenegro-Rueda, M., \& Garcia-Martinez, I. (2019). Physical education teachers and their ict training applied to students with disabilities. The case of Spain. Sustainability (Switzerland), 11(9), article number 2559.

[15] Somkin, A.A., Lyashenko, O.V., \& Konstantinov, S.A. (2019). Digital educational information service for physical education at humanities university. Teoriya i Praktika Fizicheskoy Kultury, 6, 66-68.

[16] Petrov, P.K. (2017). Information technology for physical education: Experience and challenges. Teoriya $i$ Praktika Fizicheskoy Kultury, 1, 6-8.

[17] Suzuki, N., Okuma, S., Ishizuka, S., Abe, T., Ohta, Y., \& Masuda, H. (2017). Physical education with the ict for constructivist learning. Turkish Online Journal of Educational Technology, 2017 (November Special Issue IETC), 575-580.

[18] Chen, Q. (2012). Investigation and study on information technology applications in university physical education. International Journal of Digital Content Technology and its Applications, 6(12), 265-273.

[19] Rusanov, M., \& Moskalyov, V. (2019). Requirements of modern higher education - application of information and communication technologies in physical education. Economic Strategy and Prospects of Trade and Services Sector Development, 28(2), 231-240.

[20] Kallaur, L.V. (2018). Application of information technologies in physical education of schoolchildren and students. Naukovo-Metodychni Osnovy Vykorystannia Informatsiinykh Tekhnolohii v Haluzi Fizychnoi Kultury ta Sportu, 2, 43-48.

[21] Borysova, Yu.Yu. (2015). Information technology in physical education and sports. Retrieved from https://core.ac.uk/download/pdf/214871198.pdf. 


\author{
Вікторія Володимирівна Кондратенко, Ігор Анатолійович Зайцев, \\ Олександр Миколайович Нестеренко, Людмила Василівна Гомон, \\ Геннадій Миколайович Чикольба \\ Університет митної справи та фінансів \\ 49000, вул. Володимира Вернадського, 2/4, м. Дніпро, Україна
}

\title{
Сучасні інформаційні технології в освітньому процесі з фізичного виховання у закладах вищої освіти України
}

Анотація. Актуальність дослідження визначається потребою в оновленні методів викладання фізичної культури в закладах вищої освіти на основі інформаційних технологій відповідно до соціокультурних умов сьогодення. Метою роботи є обгрунтування необхідності застосування інформаційних технологій під час фізичного виховання студентів українських вищих навчальних закладів з подальшим розробленням концептуальної моделі, спираючись на досвід зарубіжних закладів вищої освіти. Дослідження обраної проблематики відбувалося в два етапи на основі системного та інноваційного підходів з використанням методу аналізу, синтезу, узагальнення, систематизації та порівняння. У роботі було визначено необхідність впровадження інформаційних технологій в освітній процес з фізичної культури здобувачів вищої освіти на основі праць українських і зарубіжних авторів. Проаналізовано та здійснено порівняння практик використання інформаційних технологій на заняттях з фізичного виховання у вищих навчальних закладах європейських країн, таких як Іспанія, Ірландія, Португалія, Російська Федерація, а також азійських країн, серед яких знаходимо Японію та Китай. 3’ясовано, що введення засобів інформатизації в освітній процес з фізичного виховання в закладах вищої освіти України супроводжується певними труднощами, водночас, виявлено актуалізацію пошуку вирішень зазначених проблем. Розглянуто основні шляхи впровадження інформаційних технологій на заняттях з фізичного виховання в провідних вищих навчальних закладах України. Спираючись на досвід українських і зарубіжних закладів вищої освіти було розроблено концептуальну модель використання інформаційних технологій в освітньому процесі фізичного виховання студентів, в основі якої лежить вдосконалення індивідуальних і колективних навичок за допомогою універсального мобільного застосунку і фітнес-ігор. Цінність і перспективи подальших досліджень полягають у створенні універсального мобільного застосунку та впровадженні авторської методики на практиці

Ключові слова: фізичний розвиток, концептуальна модель, фізична компетентність, інформатизація, цифрові технології, вищий навчальний заклад 